\title{
The effect of supply chain practices on retailer performance with information technology as mod- erating variable
}

\author{
Zeplin Jiwa Husada Tarigan ${ }^{a^{*}}$, Juan Alexander Jiputra ${ }^{a}$ and Hotlan Siagiana
}

${ }^{a}$ Faculty of Business and Economics, Petra Christian University, Jl. Siwalankerto 121-131, Surabaya 60236, Indonesia

\section{CHRONICLE A B T RACT}

Article history:

Received: September 9, 2020

Received in revised format: September 9, 2020

Accepted: November 6, 2020

Available online: November 6, 2020

Keywords:

Supply chain practices

Information technology

Retailer performance

\begin{abstract}
Today, the retail industry has been overgrowing in offering various products to its customers. The retailer needs excellent support from the supplier to replenish the requirement based on the demand. This support can be achieved by using a secure and fast information system. Retailers, suppliers, and customers should be integrated using information technology and also practicing supply chain management for the benefit of all parties. This study examined the influence of supply chain practices on retailer performance and moderated by information technology. The study has surveyed eighty-six (86) retailer, using a questionnaire, domiciled in the city of Surabaya, Indonesia. Data analysis used SPSS software version 25 to examine the hypothesis. The results showed that supply chain practices had a direct impact on retailer performance; secondly, information technology moderated the effect of supply chain management practices on retailer performance with an increase of $14.70 \%$. Finally, information technology had an impact on increasing retailer performance. This research has an impact on modern retailers to keep adjusting their business with the use of information technology. This finding also contributes to the current research in supply chain management.
\end{abstract}

\section{Introduction}

In recent years, the retailer industry, both traditional and modern retailers, in Indonesia has indicated a high growth. During the first quarter of 2019 , the growth has reached up to $10 \%$, and it is convincing that the growth will continue in the coming months. The retailer sector still has enormous potential demand in Indonesians. East Java Province is in the top 3 ranks with the number of modern retailers in Indonesia. This position indicates that modern retailers have enormous potential and can accommodate the presence of small shops such as grocery stores and warungs (a traditional Indonesian retailer). This phenomenon is interesting to research since East Java has many big cities that have a very high purchasing power of people. The dynamic changes in business models have also made it easy for many competitors to enter this retailer business by a different business model. Indomaret retailer had the highest growth rate of 14.2 thousand outlets from January 2017 to March 2017 and was followed by Alfamart, who was in second place with 12.7 thousand outlets. Meanwhile, a modern retailer such as Hypermart, Giant, and Ramayana compete for each other in a similar market segment. There are 115 Hypermart outlets, 112 Giant outlets, and 97 Ramayana outlets, which are experiencing a downward trend due to the presence of Indomaret, Alfamart, and Alfamidi retailers which have strategic locations and are present in many locations which makes it easier for consumers to find the goods they need quickly and efficiently (Herlinda, 2019). East Java province shows a retailer industry growth rate of $3.8 \%$ and can contribute around $14.9 \%$ to public demand. However, the industry of modern retailers in Indonesia, especially in Surabaya, is considered to experience potential loss of sales up to IDR. 1.9 trillion. This loss is due to the current unfavorable * Corresponding author. Tel.: +62312983145

E-mail address: zeplin@petra.ac.id (Z. J. H. Tarigan)

C 2021 by the authors; licensee Growing Science, Canada. doi: $10.5267 /$ j.ijdns.2020.11.003 
environmental conditions, the pandemic which has caused restrictions on visitors to enter, and social restrictions imposed in the city of Surabaya (Wijayanto, 2019). This condition, of course, will become a challenge for retailers on how to survive and to minimize the losses. Besides, intense competition has forced retailers to be more creative in providing attractive promotions. The locations used by these retailers have also been adjusted based on market demand. Also, the presence of modern retailers provides distinctive advantages for consumers because consumers favor shopping at retailers that are closer to their homes even though the price is higher than wholesalers. Even so, this business competition can be said to be quite tight and often leads to unfair competition. Retailers in society can determine changes in existing consumption, especially the number of retailers that have adopted information technology (Lehner, 2015). One retailer company will always compete in achieving performance and competitiveness, generally measured by-product prices, product quality, services provided to customers, and strategic retailer locations for customers (Petljak et al., 2017). The question raised is how to survive and improve the retailer performance amid the current pandemic. Researches have argued that the retailer should be creative and innovative to find the best solution to overcome the on-going situation.

Information technology in an organization aims to help improve the performance of its employees, information technology is also often contained in the company's mission and vision, business objectives, operating procedures, in increasing the company's competitiveness (Tarigan et al., 2019). The implementation of the information technology application helps support the activities of supply chain management and becomes important in the context of increasing economic competition both locally and globally ( $\mathrm{Li}$ et al., 2009, Mavengere, 2013). Information technology enables retailers and suppliers to collaborate in supply chain management, such as sharing data and information to identify changes in the market and assisting in taking appropriate actions such as moving facilities, changing suppliers, and outsourcing (Ketchen \& Hult, 2007). The influence of information technology on the relationship between buyers and suppliers (Kim, 2008). The information technology investment in supply chain management has varied the results and have dynamic interactions between the three feedback loops that represent information technology (Chae et al., 2018). IT success depends on relationships between vendor and client (Okundaye et al., 2019). An outsourcing relationship is a long-term relationship between the vendor and the client (Chakrabarty and Whitten, 2011). The relationship has a long-term orientation and mutual recognition and understanding that the benefits obtained by each company depending on the other company. Supply chain management is also one of the tools used by organizations to improve their business performance as well as to maintain their competitive advantage because the competition is between supply chains and not between individual organizations. (Attia, 2016).

$\mathrm{Vu}$ et al. (2020) stated that supply chain activity as a form of supply chain practices for retailer business found that collaboration, information technology, inventory, manufacturing, location, and transportation determine the direction of the supply chain strategy. Supply chain activities that are carried out in practice can result in increased competitiveness; especially inretailer performance compared to its competitors. Supply chain practice can provide an increase in supply chain performance efficiency at food retailer companies in Australia (Jie \& Gengatharen, 2019). Supply chain practices related to company suppliers in strategic supplier partnerships, information sharing with suppliers, information quality with suppliers, and integration intensity with suppliers can increase the retailer performance (Hamister, 2012). Supply chain management practices in manufacturing companies can have an impact on firm performance manufacture (Al-Shboul et al., 2018, Tarigan et al., 2020). Supply chain practices related to downstream customer focus and upper stream supplier focus are determined mainly by the use of information technology so that there is supply chain integration in the company's supply chain flow (Tarigan et al., 2020). Research conducted by Gandhi et al. (2017) states that supply chain practices determined from the dimensions of customer relationship management, supplier relationship management, goal congruence, and information sharing provide improvements in company performance and supply chain performance. Firm performance can be improved by adopting supply chain practices in companies (Sundram et al., 2011). SCM practice can have an impact on firm performance and competitive advantage (Ince et al., 2013, Truong et al., 2017).

The manufacturing companies used information technology to integrate the external and internal parties (Baheshti et al., 2014). The information technology is adopted to provide increased performance for companies engaged in retailer business. Based on the above discussion, this research has set research objectives. Firstly, supply chain management practices can have an impact on company performance. Secondly, the implementation of information technology can increase company performance and, thirdly, that the implementation of information technology can moderate the influence of supply chain management practices on the increase in firm performance.

\section{Supply chain management}

Supply chain management is an activity to plan and regulate all activities related to the procurement of raw materials, changing forms, and all logistics management activities (Tarigan et al., 2019). SCM also includes coordination and collaboration with related partners, which can be suppliers, intermediaries, third parties as service providers, and customers, or consumers. SCM integrates supply and demand arrangements within or between companies (Siagian et al., 2020). Every relationship in a supply chain signifies a relationship between a particular customer and a particular supplier; this association aims to provide direct customer delivery requirements and then replicate practices throughout the supply chain for the benefit of the end consumer (Gorane \& Kant, 2016). 
SCM has the aim of regulating production needs starting from raw materials and various other components to be converted into semi-finished goods or finished goods, then stored as inventory and ready to be distributed to consumers. The supply chain starts from the point of production to the point of consumption, on the other hand. The supply chain consists of several different companies and organizations that work together to produce value in the form of goods or services (Vural, 2015, Ketchen \& Hult, 2007). SCM works to bring suppliers, distributors, and consumers into a cohesive process (Gandhi et al., 2017). Manufacturers, suppliers, transporters, warehousing, retailers, and consumers are involved in a constant but always dynamic flow of information, products, and money (Sundram et al., 2018). SCM has also become a supply network or supply web because it can show how a unit in a supply chain interacts with one another. Suppliers and distributors who were once opposites are now partners for the good of both parties. SCM manages all processes in a complex chain and always improves product quality and customer satisfaction effectively; this is called SCM (Truong et al., 2017).

\subsection{Supply Chain Practices}

Supply chain practices is a practical activity carried out by companies in the supply chain flow in order to improve company performance and competitiveness of companies along with the supply chain flow (Tarigan et al., 2019). Supply chain practices that can improve supply chain performance with practical activities include building strategic alliances, building customer relationship management, conducting an information sharing with company partners, quality of information sharing internal and external companies, and implementing lean thinking (Jie and Gengatharen). Supply chain practices determine retailer performance by carrying out supply chain practice activities, including strategic supplier partnerships, information sharing, information quality, and integration intensity (Gorane and Kant, 2016, Hamister 2012). Supply chain management practices consist of two streams, namely downstream, which focuses on customers and upstream, which focuses on suppliers (Tarigan et al., 2020). Supply chain practices proposed by Al Al-Shboul et al. (2018) are collaborations built with suppliers, the flexibility built into suppliers, the use of internet technology, customer focus, lean production on manufacture, integrated internal integration, and quality management. Customer relationship management, supplier relationship management, goal congruence, and information sharing are dimensions of supply chain management practice (Gandhi et al., 2017). Supply chain practices consist of eight dimensions, namely strong strategic supplier partnerships, excellent customer relationships, information sharing with company partners, information quality, postponement, agreed and vision, and risk and reward sharing (Sundram et al., 2011). Supply chain practices also consist of upstream, focal company, and downstream. Supply chain practice has four dimensions in a company, namely lean practice (waste elimination, total quality management, just in time and cleaner production), resilient practice (flexible sourcing, supply chain risk management, and flexible transportation) and green practice, including ISO 14001 certification. Research conducted by Ince et al. (2013) states that strategic partnerships measure supply chain practice with suppliers, customer relationships, and levels of information quality and sharing. Supply chain practices that focus on the environment are called green supply chain management practices, which consist of supplier selection and evaluation, supplier manages inventory, investment recovery, eco-design and packaging, reverse logistics and corporation with customers (Sundram et al., 2018).

\subsection{Information Technology}

Companies use technology in order to be able to integrate company activities in practice can be known quickly in information technology systems (Lehner, 2015). The activities along the supply chain can be identified by the company in detail when starting from receiving orders, planning production, entering and leaving of materials and supporting materials from the warehouse, material procurement, company inventory positions and product delivery using information technology implemented by the company (Okundaye et al., 2019). The information technology used by the company can sustainably accelerate supply chain practice and is useful in improving company performance (Mavengere, 2013, Chae et al., 2018)). SCM practice in companies driven by an ERP system can have a significant impact on firm performance and competitive advantage (Ince et al., 2013). The ERP system used is measured by systems and information quality, system use, individual impact, and organizational impact (Tarigan et al., 2020). The effectiveness of supply chain practices can have an impact on the company's success in improving company performance, which is accelerated by the existence of system integration in the company (Siagian et al., 2020). An organization must be able to plan and integrates all functions within the company and also integrate effectively with external parties as to the company's business partners (Baheshti et al., 2014; Govindan et al., 2014). Supply chain practices have an impact on manufacturing firm performance by using information technology in the form of supply chain integration as an intervening variable. The use of information technology enables companies to integrate within the company, integration with suppliers, and integration with customers (Sundram et al., 2018).

\subsection{Retailer Performance}

Retailer performance is the achievement of targets or goals in a certain period. Retailer performance can determine the increase in retailer competitiveness compared to other retailers. Retailer performance used the indicators suggested by Ltifi and Gharbi (2015), namely the availability of inventory, there is no stock out, product information, ease of shopping or purchases, and ease of returning goods to retailers. The retailer performance measures the competitiveness, which is traditionally determined by the price of the product, the quality of the product produced, the services provided, and the strategic location owned by the retailer (Petljak et al., 2017). Manufacturing companies should provide service to the retailer to improve retailer performance. The services provided consists of the following terms: efficient order process, mismatched orders rectification, promised lead 
time, particular order lead time, consistency of deliveries as promised, speed of delivery before the due date, consistency with the quantity promised, order accuracy, and the company's ability to deliver undamaged products (Davis-Sramek et al., 2008 ). Measurement items used to assess supply chain performance at a retailer in Australia are low inventory costs, high labor costs, low transportation costs, minimal waste costs, and increased profits (Jie and Gengatharen, 2019). Hamister (2012) suggested the measurement items of retailer performance, namely volume flexibility, schedule flexibility, on-time delivery, and delivery reliability/consistency. Meanwhile, Gandhi et al., (2017) suggested eight indicators to measure supply chain performance at manufacturing companies: forecasting and planning material requirements with high accuracy; the company has a timely delivery of products; reliable supplier with proper delivery, reliability, and consistency; the company can control costs and supply chain knowledge; companies have a fast response time, and the company has the right level of inventory.

\section{Research methods}

This study focused on the population of retailers that have used information technology in providing service to customers and has been well-coordinated through information technology in ordering goods to manufacturing companies as suppliers. A modern retailer is a retailer whose system has been integrated with its partners in performing the procurement of goods and inventory at the retailer storage. One of the objectives of this study is to obtain a moderation effect of information technology on retailer performance from the implementation of supply chain practices (Fig. 1). The data used were as many as 86 modern retailers.

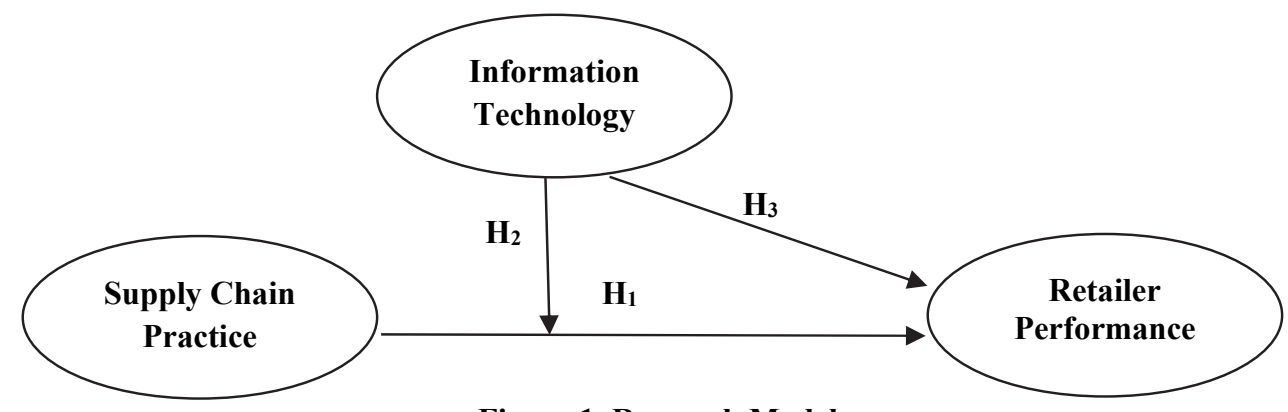

Figure 1. Research Model

Fig. 1 demonstrates the research model, and the three hypotheses developed as follows:

$\mathrm{H}_{1}$ : Supply chain practice affects retailer performance.

$\mathrm{H}_{2}$ : Information technology moderates the relationship between supply chain practice and retailer performance.

$\mathrm{H}_{3}$ : Information technology improves retailer performance.

The measurement used for supply chain management practices is strategic supplier partnership (SCP1), information communicated (SCP2), sharing of quality of information (SCP3), and demand management interaction (SCP4). For information technology, six indicators are used to assess the extent to which the retailer and supplier have implemented information technology, which is reliability (TI1), objectivity (TI2), timeliness (TI3), value-added (TI4), richness (TI5), and provided in a proper format (TI6). The measurements used for retailer performance are ordering procedure (RP1), order discrepancy handling (RP2), order lead time variation (RP3), timeliness (RP4), product availability (RP5), order condition (RP6). Data analysis used SPSS version 25 with multiple linear analyses to examine the three research hypotheses (Sekaran \& Bougie, 2016). The acceptance of the hypothesis is based on the t-statistic value obtained from the multi regression technique.

\section{Analysis and discussion}

The object in this research is the modern retailer, which engaged in the sale of Fast-Moving Consumer Goods (FMCG) products in the city of Surabaya. Researchers distributed as many as 86 questionnaires, in the form of hardcopy, to the retailer that met the criteria for the research sample, namely modern retailers engaged in FMCG. Characteristics of respondents in terms of gender consists of the male 56 respondents (65.11\%), and female respondents are 30 respondents (34.89\%). Majority of the respondent is male because the retailer views that men are more capable of maintaining shops than women. Males are more suitable in the point of view of security if something happens, such as robbery. Most of modern retailers are open 24 hours so that men are seen as more secure and able to take care of themselves. However, females are considered to be more careful in checking the retailer inventory.

Based on the working experience, the modern retailer in the city of Surabaya, the retailer manager has worked for 4 to 6 years amounted to $37(43.02 \%), 7$ to 9 years amounted to $23(26.74 \%), 1$ to 3 years 15 respondents $(17.44 \%)$, and less than one year seven respondents $(8.13 \%)$, more than ten years amounted to $4(4.67 \%)$. This finding shows that the majority has worked for 4 to 6 years. The result indicated that the owner needs more time to see and assess the performance of each employee before they deserve to be the head of the retailer. 
The detailed analysis result related to the score of respondents' responses to the items is illustrated in Table 1.

Table 1

Descriptive analysis result

\begin{tabular}{|c|c|c|c|c|c|c|c|}
\hline Items & Statement & $\begin{array}{c}\text { Std. } \\
\text { Deviation }\end{array}$ & Average & Items & Statement & $\begin{array}{c}\text { Std. } \\
\text { Deviation }\end{array}$ & Average \\
\hline SCP1 & Strategic supplier partnership & 0.595 & 4.37 & RP1 & Ordering procedure & 0.586 & 4.44 \\
\hline $\mathrm{SCP} 2$ & Level of information sharing & 0.564 & 4.43 & RP2 & handling of order discrepancies & 0.636 & 4.38 \\
\hline SCP3 & Quality information sharing & 0.561 & 4.41 & RP3 & Order lead time variation & 0.528 & 4.29 \\
\hline SCP4 & Customer relationship management & 0.600 & 4.40 & RP4 & Timelines & 0.526 & 4.49 \\
\hline TI1 & Reliability & 0.500 & 4.66 & RP5 & Product availability & 0.588 & 4.47 \\
\hline TI2 & Objectivity & 0.548 & 4.49 & RP6 & Order condition & 0.608 & 4.47 \\
\hline TI3 & Value Added & 0.547 & 4.52 & & & & \\
\hline TI4 & Timeliness & 0.612 & 4.36 & & & & \\
\hline TI5 & richness & 0.523 & 4.44 & & & & \\
\hline TI6 & format & 0.546 & 4.23 & & & & \\
\hline
\end{tabular}

Table 1 demonstrates that indicators of supply chain management practices have the lowest average of 4.37 , the strategic supplier partnerships. This indicator indicated the extent to which the supplier and retailer have established a long-term relationship that focused on joint planning and problem-solving efforts. The indicator of supply chain management practices with the highest score of 4.43 is the level of information sharing (the extent to which information communicated with partners in the supply chain). This result shows that in practice, retailers have a good relationship with their suppliers, in this case, retailers always inform suppliers before changes in needs occur, so that suppliers have time to prepare their needs from the retailer. Besides, Table 1 also shows that the indicator information technology has the lowest average format value of 4.23 (the information technology used can provide data according to the needs of the company in proper format), and the indicator with the most significant score of 4.66 is reliability, the information technology adopted by the company is highly reliable. This result shows that in practice, suppliers always provide factual and reliable information to the retailers to help increase retailer sales. Furthermore, Table 1 indicated the indicator of retailer performance with the lowest score average of 4.29 that order lead time variation is high. The indicator of retailer performance with the biggest score of 4.49 is that the supplier ship products correctly. This finding shows that in practice, the supplier always sends the product correctly without error to the retailer, and it will increase the performance of the retailer. Further analysis is the examination of the three hypotheses. The analysis used the linear regression model between supply chain performance and retailer performance, and the results are shown in Table 2, Table 3, and Table 4.

Table 2

R-Square Value of Supply Chain Management Practice

\begin{tabular}{lcccc}
\hline Model & $\mathrm{R}$ & $\mathrm{R}$ Square & Adjusted R Square & Std. An error of the Estimate \\
\hline 1 & $.637^{\text {a }}$ & .405 & .398 & .3804 \\
\hline
\end{tabular}

a. Predictors: (Constant), Supply Chain Management Practice

Table 3

F-test results of supply chain management practice

\begin{tabular}{llcccc}
\hline Model & & Sum of Squares & df & Mean Square & Sig. \\
\hline 1 & Regression & 8.284 & 1 & 8.284 & $.000^{\mathrm{b}}$ \\
& Residual & 12.155 & 84 & .145 & \\
\cline { 2 - 6 } & Total & 20439 & 85 & \\
\hline
\end{tabular}

a. Dependent Variable: Retailer Performance

b. Predictors: (Constant), Supply Chain Management Practice

Based on the results of Table 2, the variances of retailer performance can be explained by the Supply Chain Management Practice variance up to $40.50 \%$, while the other variances are explained by variables that have not been determined in this study. The F test in Table 3 illustrates that the Supply Chain Management Practice variable affects retailer performance significantly with a significant level $<0.05$. This finding empirically supports that the model of that the research model can be used the predict the retailer performance.

Table 4

T-test results of supply chain management practice

\begin{tabular}{|c|c|c|c|c|c|c|}
\hline \multirow[b]{2}{*}{ Model } & & \multicolumn{2}{|c|}{ Unstandardized Coefficients } & \multirow{2}{*}{$\begin{array}{c}\text { Standardized Coefficients } \\
\text { Beta }\end{array}$} & \multirow[b]{2}{*}{$\mathrm{t}$} & \multirow[b]{2}{*}{ Sig. } \\
\hline & & $\mathrm{B}$ & Std. Error & & & \\
\hline 1 & (Constant) & 1.006 & .453 & & 2.220 & .029 \\
\hline & Supply Chain Management Practice & .767 & .101 & .637 & 7.566 & .000 \\
\hline
\end{tabular}

a. Dependent Variable: Retailer Performance

Based on Table 4, the supply chain practices had a significant impact on the retailer performance with a coefficient of 0.767 and sig. level of 0.000 . This result proved that the first hypothesis could be accepted, the improvement in Supply Chain Management Practice increase in retailer performance. 
Table 5

R-square of information technology

\begin{tabular}{lccc}
\hline Model & $\mathrm{R}$ & $\mathrm{R}$ Square & Adjusted R Square \\
\hline 1 & $.740^{\mathrm{a}}$ & .547 & .530 \\
\hline a. Predictors: (Constant), Moderator, Supply Chain Management Practice, Information Technology
\end{tabular}

a. Predictors: (Constant), Moderator, Supply Chain Management Practice, Information Technology

Table 5 shows that the role of information technology as a moderating variable exists. The variance of retailer performance explained by the Supply Chain Management Practice on retailer performance is greater than that of without the presence of the moderating variable. The R-square value is $0.547>0.405$ (without moderating variable). This finding shows that the moderating effect of information technology exists between supply chain management practices and retailer performance. In Table 2, the R-square between Supply Chain practices and retailer performance is $40.50 \%$. There is an increase in R-square by $14.70 \%$ so that information technology can moderate the effect of supply chain practice on retailer performance. This finding supports the second hypothesis that information technology moderates the relationship between supply chain management practices and retailer performance.

Table 6

F test results of information technology

\begin{tabular}{llcccc}
\hline Model & & Sum of Squares & df & Mean Square & F \\
\hline 1 & Regression & 11.181 & 3 & 3.727 & 33.010 \\
& Residual & 9.258 & 82 & .113 & \\
\cline { 2 - 6 } & Total & 20.439 & 85 & & \\
\hline
\end{tabular}

a. Dependent Variable: Retailer Performance

b. Predictors: (Constant), Moderator, Supply Chain Management Practice, Information Technology

Table 6 illustrated the result of the $\mathrm{F}$ test for linear regression between information technology, supply chain management practices, and retailer performance as the $\mathrm{F}$ value is 33.010 and the significant level is $0.000<0.05$. It means that the model involving all the variables is acceptable. Table 6 also illustrates that supply chain management practices, information technology, and the role of information technology as a moderator can simultaneously impact retailer performance.

Table 7

T-test results for information technology as moderating variable

\begin{tabular}{|c|c|c|c|c|c|c|}
\hline \multirow[b]{2}{*}{ Model } & & \multicolumn{2}{|c|}{ Unstandardized Coefficients } & Standardized Coefficients & \multirow[b]{2}{*}{$\mathrm{t}$} & \multirow[b]{2}{*}{ Sig. } \\
\hline & & $\mathrm{B}$ & Std. Error & Beta & & \\
\hline \multirow[t]{4}{*}{1} & (Constant) & 4.276 & 4.076 & & 1.049 & .297 \\
\hline & Supply Chain Management Practice & .416 & .939 & .345 & 2.443 & .039 \\
\hline & Information Technology & .502 & .925 & .488 & 2.543 & .028 \\
\hline & Moderator & .214 & .211 & .454 & 2.013 & .043 \\
\hline
\end{tabular}

a. Dependent Variable: Retailer Performance

Besides, Table 7 illustrates that supply chain management practices can influence retailer performance, as indicated by the sig value. $0.039<0.05$, and information technology is also able to significantly influence the increase in retailer performance by $0.028<0.05$, and the moderating effect of information technology with the sig. level of $0.43<0.05$. These results suggest that the third hypothesis, namely information technology, has an acceptable impact on retailer performance. Information technology can build internal and external company integration, both supplier integration and customer integration so that it can have a strong influence on supply chain management practices on retailer performance.

\section{Conclusion}

The main objective of this study was to examine the effect of supply chain practices on retailer performance with the moderating role of information technology. The result revealed that supply chain practices enable the retailer to improve the performance by connecting the retailer and the supplier and the customer. Information technology is a very useful tool to enhance the effect of supply chain practices on retailer performance. Beside moderating, information technology also directly improves retailer performance. The adoption of information technology provides a double impact in enhancing retailer performance as a direct and moderating impact. The use of information technology can increase the company's integration with its suppliers and customers. Information technology assists the retailer's achieve excellent effectiveness and efficiency in the pursuit of better retailer performance. This study could provide a new insight for the retailer manager on how to enhance retailer performance through supply chain practices and the adoption of information technology. This research also contributes to enriching the on-going research in the field of supply chain management.

\section{References}

AL-Shboul, M.A., Garza-Reyes, J.A., and Kumar, V. (2018). Best supply chain management practices and high-performance firms: The case of Gulf manufacturing firms. International Journal of Productivity and Performance Management, 67(9), 1482-1509. https://doi.org/10.1108/IJPPM-11-2016-0257 
Attia, M.A. (2016a). Effect of quality management on supply chain and organisational performance in the Egyptian textile industry. International Journal Business Performance Management, 17(2), 198-222.

Baheshti, HM, Oghazi, P., Mostaghel, R., \& Hultman, M. (2014). Supply chain integration and firm performance: an empirical study of Swedish manufacturing firms. Competitiveness Review, 24(1), 20-31.

Chae, H.-C., Koh, E.C., \& Park, K.O. (2018). Information technology capability and firm performance: Role of industry. Information \& Management, 55(5), 525-546

Davis-Sramek, B., Mentzer, JT, \& Stank, TP (2008). Creating consumer, durable retailer customer loyalty through order fulfillment service operations. Journal of Operations Management, 26(6), pp. 781-797.

Gandhi, A.V., Shaikh, A., \& Sheorey, P.A. (2017). Impact of supply chain management practices on firm performance: Empirical evidence from a developing country. International Journal of Retailer \& Distribution Management, 45(4), 366384.

Gorane, S.J., \& Kant, R. (2016). Supply chain practices: An implementation status in Indian manufacturing organisations. Benchmarking: An International Journal, 23(5), pp.1076-1110

Govindan, K., Azevedo, S.G., Carvalho, H., and Cruz-Machado, V. (2014). Impact of supply chain management practices on sustainability. Journal of Cleaner Production, 85, 212-225.

Hamister, J.W. (2012). Supply chain management practices in small retailers. International Journal of Retail \& Distribution Management, 40(6), 427-450.

Herlinda, W. D. (2019). Bisnis ritel modern ditarget tumbuh 10\% [The modern retail business is targeted to grow 10\%], Available https://ekonomi.bisnis.com/read/20190107/12/876089/2019 -bisnis-ritel-modern-ditarget-tumbuh-10 (June 25, 2020).

Ince, H., Imamoglu, S.Z., Keskin, H., Akgun, A., \& Efe, M.N. (2013). The impact of ERP systems and supply chain management practices on firm performance: Case of Turkish companies. Procedia - Social and Behavioral Sciences, 99, $1124-$ 1133.

Jie, F. and Gengatharen, D. (2019). Australian food retail supply chain analysis. Business Process Management Journal, 25(2), pp. 271-287.

Ketchen, J. D. J., \& Hult, G. T. M. (2007). Bridging organization theory and supply chain management: the case of best value supply chains. Journal of Operations Management, 25(2), 573-580

Kim, S. W. (2008). The Effect of Information Technology on Arms-Length Buyer-Supplier Relationship. Asian Journal on Quality, 9(3), 57-69.

Lehner, M. (2015). Translating sustainability: the role of the retailer store. International Journal of Retailer \& Distribution Management, 43(4-5), 386-402.

Li, G., Yang, H., Sun, L., \& Sohal, A. S. (2009). The impact of IT implementation on supply chain integration and performance. International Journal of Production Economics, 120(1), 125-138.

Ltifi, M., and Gharbi, J. (2015). The effect of logistics performance in retailer store on the happiness and satisfaction of consumers. Procedia Economics and Finance, 23, 1347-1353.

Mavengere, N.C. (2013). Information technology role in supply chain's strategic agility. International Journal Agile Systems and Management, 6(1), 7-24

Okundaye, K., Fan, S.K., and Dwyer, R.J. (2019). Impact of information and communication technology in Nigerian smallto medium-sized enterprises. Journal of Economics, Finance and Administrative Science, 24(47), 29-46.

Petljak, K., Zulauf, K., Štulec, I., Seuring, S., \&Wagner, R. (2018). Green supply chain management in food retailers: surveybased evidence in Croatia. Supply Chain Management: An International Journal, 23(1), 1-15,

Sekaran, U., \& Bougie, R. (2016). Research methods for business: A skill building approach. United Kingdom: John Wiley $\&$ Sons.

Siagian, H., Jade, K., \& Tarigan, Z. J. H. (2020). The role of affective leadership in improving firm performance through the integrated internal system and external integration FMCG Industry. International Journal of Data and Network Science, 4(4), 365-372

Sundram, V.P.K, Rajagopal, P., Bahrin, A.S., and Subramaniam, G. (2018). The role of supply chain integration on green practices and performance in a supply-chain context: A conceptual approach to future research. International Journal of Supply Chain Management, 7(1), 95-104.

Sundram, V.P.K., Ibrahim, A.R., and Govindaraju, V.G.R.C. (2011). Supply chain management practices in the electronics industry in Malaysia: Consequences for supply chain performance. Benchmarking: An International Journal, 18(6), pp. 834-855.

Tarigan, Z.J.H., Siagian, H., \& Bua, R.R. (2019). The impact of information system implementation to the integrated system for increasing the supply chain performance of manufacturing companies. IOP Conf. Series: Materials Science and Engineering, 473, 012050.

Tarigan, Z.J.H., Siagian, H., \& Jie, F. (2020). The role of top management commitment to enhancing the competitive advantage through ERP integration and purchasing strategy. International Journal of Enterprise Information Systems, 16(1), 53-68

Tarigan, Z.J.H., Siagian, H., \& Suprapto, W. (2020). The Effect of Middle Manager Engagement on SCM Performance through ERP System and SCM Practices. Proceedings WCSE Summer, pp. 47-51. 
Truong, H.Q., Sameiro, M., Fernandes, A.C., Sampaio, P., Duong, B.A.T., Duong, H.H., \& Vilhenac, E. (2017). Supply chain management practices and firms'operational performance. International Journal of Quality \& Reliability Management, 34(2), pp.176-193

Vu, T.H., Tran, H.L., Le, T.T., Nguyen, M.D., \& Duong, B.N. (2020). Relationship between supply chain activities in Vietnamese retailer business enterprises. Uncertain Supply Chain Management, 8, 321-330.

Vural, C.A (2015). Sustainability Demand Chain Management: An Alternative Perspective for Sustainability in the Supply Chain. Procedia-Social and Behavioral Sciences, 207, 262- 273.

Wijayanto. (2019). Industri ritel bersaing ketat, kinerja tumbuh tipis [The retail industry is tight competitive, the performance is growing thin], Available: https://radarsurabaya. jawapos.com/read/2019/06/27/143445/industri-ritel-bersaing-ketatkinerja -tumbuh-tipis (July 5, 2020).

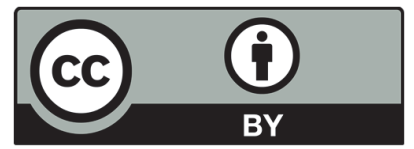

(C) 2021 by the authors; licensee Growing Science, Canada. This is an open access article distributed under the terms and conditions of the Creative Commons Attribution (CC-BY) license (http://creativecommons.org/licenses/by/4.0/). 